مجلة دراسات في المناهج وطرق التدريس، الترقيم الدولي (ISSN 2535-213X)/ العدد 244 (2019م)

\title{
Using the 5 E's Instructional Model to Enhance English Grammar Learning of Secondary Stage Students
}

Dr. Sara Mohamed Naguib ${ }^{1}$

Lecturer, Curriculum and Instruction Department, Faculty of Education, Port Said University

\section{Abstract}

The purpose of this study was to investigate the impact of using the 5 E's instructional model on secondary stage students' grammar learning. The model was applied by ten prospective teachers in five secondary stage classes to teach English grammar. A qualitative assessment questionnaire designed by the researcher was used for investigating improvement in students' learning of grammar and for evaluating the application of the model in English teaching. Results showed significant improvement in students' learning of grammar which proves that the5 E's instructional model can be used to enhance English learning in TEFL classes.

Keywords: the 5 E's instructional model, grammar learning, TEFL classes.

\footnotetext{
${ }^{1}$ Lecturer, Curriculum and Instruction Department, Faculty of Education, Port Said University
} 
مجلة دراسات في المناهج وطرق التّريس، الترقيم الدولي (ISSN 2535-213X)/ العدد 244 (2019م)

استخدام نموذج " 5 E's" التعليمى فى تحسين تعلم قواعد اللغة الإنجليزية لاى

طلاب المرحلة الثانوية

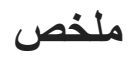

هدفت هذه الدر اسة إلى التحققق من أثر استخدام نموذج "5's 5 " التعليمي على تعلم طلاب المرحلة الثانوية لقو اعد اللغة الإنجليزية. قام بنطبيق النموذج أثناء تدريس قو اعد اللغة الإنجليزية عشرة من الطلاب المعلمين خلال التدريب الميدانى داخل خمس فصول فى المرحلة الثانوية. استخدمت الدر اسة استبيان التقييم النو عي الذي صممته الباحثة للتحقق من تحسن تعلم الطلاب لقو اعد اللغة و كذلك لتقييم تطبيق النموذج فى تدريس اللغة الإنجليزية. أظهرت النتائج تحسنًا ظاهر ا في تعلم الطلاب لقو اعد اللغة مما يثبت أنه يمكن استخدام نموذج " 5 E's' " لتحسين التعلم فى فصول تدريس اللغة الإنجليزية كلغة أجنبية.وقدمت الدراسة أكثر من تطبيق تربوى للنموذج وأوصت باستخدامه لتحقيق أغر اض تربوية متعددة فى مجال تدريس اللغة الإنجليزية.

الكلمات المفتاحية: نموذج "E's' 5 " التعليمى ، تعلم قو اعد اللغة الإنجليزية، ، فصول تدريس اللغة الإنجليزية كلغة أجنبية. 


\section{Introduction}

Many fields of education use the 5 E's instructional model. Despite its popularity, the model's application in the field of teaching English is limited. The model has five phases; each begins with the letter 'e'. The phases are represented by the verbs: engage, explore, explain, elaborate, and evaluate.

Engage is the first phase of the 5 E's model in which students make connections between past and present learning experiences and become mentally engaged in the concept, process, or skill to be learned. Explore is the second phase of the 5 E's that provides students with a common base of experiences to develop concepts, processes, and skills. As for the third phase, explain, it provides opportunities for students to verbalize their conceptual understanding or to demonstrate new skills and also provides opportunities for teachers to introduce formal terms. In the fourth phase, elaborate, students extend their conceptual understanding and practice skills. The final phase in the model is evaluate. In this phase students assess their understanding and abilities and teachers evaluate students' understanding of key concepts and skill development.

The 5 E's instructional model is based on the constructivist approach to learning. With a constructivist approach, students synthesize new understanding from prior learning and new information. The constructivist teacher asks students to work with their own data and learn to direct their own explorations. Constructivist approaches work well with learners of all ages, including adults. Similarly, the 5 E's can be used with students of all ages. 
مجلة دراسات في المناهج وطرق التتريس، الترقيم الدولي (ISSN 2535-213X)/ العدد 244 (2019م)

The following study investigates the effectiveness of the model in teaching English grammar to EFL learners. Most EFL learners, as previous research has noted, have difficulty in learning grammar rules (Brown, 2007; Mohammed and Jaber, 2008; Obaid, 2010; El-Tanani, 2011; Dang and Nguyen, 2012; Zamani and Mohammadi, 2014; and Negahdaripour and Amirghassemi, 2016).

Grammar certainly received proper focus in the TEFL research. Reviewing previous research on grammar teaching and learning in the EFL context shows that there are essential issues that received focus. Among these issues, there is the preference between the inductive and the deductive methods for grammar teaching. In this concern, Brown (2007, p. 423) discusses the following question: "should grammar be presented inductively or deductively?" In an Inductive method, various language forms are practiced but learners are left to discover rules on their own. However, in a deductive method, learners are given rules by the teacher or textbook and then practice various instances of language to which the rule applies.

In that sense, previous research has studied the effects of using inductive and deductive approaches and the interaction between these approaches for teaching grammar in an EFL context. The results indicate significant differences in favor of the deductive group (Mohammed and Jaber, 2008; Dang and Nguyen, 2012; and Negahdaripour and Amirghassemi, 2016) However, other studies that have attempted to find differences between inductive and deductive methods in teaching grammar have found no evidence of significant differences between the two methods (Zamani and Mohammadi, 
مجلة دراسات في المناهج وطرق التتريس، الترقيم الدولي (ISSN 2535-213X)/ العدد 244 (2019م)

2014). Thus, there is not an agreement on which approach is more effective to teach grammar in an EFL context and the debate is still open in this respect.

Moreover, reviewing previous research on grammar teaching and learning points out that there are some common treatments that were applied for the purpose of improving grammar. Examples of these treatments are: Teaching grammar through writing as recommended in Weaver, Nally, and Moerman (2001) and Thornbury (2004), though drama and literature as applied in the study of Boudreault (2010), through songs as outlined by Orlova (2003) and Brown (2006), and through games and problem-solving activities as in the study of Saricoban and Metin (2000).

From another perspective, the researcher in the present study applied a new treatment, the 5 E's instructional model, in teaching EFL learners grammar rules. There is a relation between the model phases and grammar learning. In other words, there is a similarity between the phases that compose the model and the three phases of teaching grammar. Basically, effective grammar lessons are usually composed of three phases: presentation, practice, and production (Brown, 2000; Harmer, 2001). To help students reach the objectives of the lesson, teacher introduces the new language well in the first phase of the lesson: this is the presentation phase. Then, students need to have plenty of activities to help them to practice the new language: this is the practice phase. Lastly, the students need time to use the new language they have learned: this is the production phase. The three phases of grammar teaching are actually included in the phases of the 5E's model. Engagement and exploration represent the presentation phase. Explanation and elaboration 
مجلة دراسات في المناهج وطرق التتريس، الترقيم الدولي (ISSN 2535-213X)/ العدد 244 (2019م)

stand for the practice phase. Evaluating students' responses or answers reflects the production phase. The similarity between both phases, of teaching grammar and of the 5E's model, represents the rationale or the logical reason for the applicability of using the 5E's model to teach English grammar.

Secondary stage students find grammar the most difficult in their English learning. They lack the ability to connect prior knowledge with new grammar rules. Moreover, they have difficulty in the application of what they learned in producing correct sentences in an oral or a written form. In other words, they face difficulty in connecting the theoretical knowledge they gained and the skills they must perform. This problem was noticed by the researcher while attending English classes in many secondary schools during practicum supervision. Interviewing English teachers and supervisors confirmed the problem. Reviewing previous literature also proves that many researchers, such as Mohammed and Jaber (2008); Obaid (2010); El-Tanani (2011); and Jendeya (2015), noticed the grammar learning problem and focused on improving grammar learning using various independent variables.

\subsection{Statement of the Problem}

The problem of the study thus can be identified as follows: Secondary stage students have difficulty in learning grammar and inability to connect between the theoretical knowledge they gained and the skills they must perform. Hence, this study sought to find an answer to the following main question: How does grammar learning of secondary stage students improve as a result of using the 5 E's instructional model? 
مجلة دراسات في المناهج وطرق التتريس، الترقيم الدولي (ISSN 2535-213X)/ العدد 244 (2019م)

The following sub-questions were also answered:

1- What are the main features of the 5 E's instructional model?

2- How far is the 5 E's instructional model effective in enhancing English grammar learning of secondary stage students?

\subsection{Purpose of the Study}

The purpose of the study was to determine the effect of using the 5 E's instructional model in enhancing English grammar learning of secondary stage students.

\subsection{Significance of the Study}

The significance of the study stems from the following considerations:

- The treatment and the instrument presented in the study might be beneficial to EFL researchers.

- The treatment and the teaching sample might be beneficial to EFL teachers.

- The study might provide guidelines upon which further treatments may be designed to develop various skills of EFL learners.

\subsection{Limitations of the Study}

This study was restricted to:

- The five phases included in the 5E's instructional model.

- The qualitative assessment questionnaire to investigate the impact of using the model in enhancing grammar learning. 
مجلة دراسات في المناهج وطرق التتريس، الترقيم الدولي (ISSN 2535-213X)/ العدد 244 (2019م)

- A sample of secondary stage students.

- Prospective teachers to apply the model in their teaching classes during practicum.

\subsection{Definition of Terms}

\section{The 5E's instructional model}

Bybee (1997, p.176) defines the 5E's instructional model as an approach that allows students redefine, reorganize, elaborate, and change their initial concepts through self-reflection and interaction with their peers and their environment.

According to Anil and Batdi (2015, p.212), the 5E's instructional model is a five stages based model that is considered one of the most useful forms in designing teaching processes based on the constructivist theory of learning. The different stages of learning included in the model are: engage, explore, explain, elaborate and evaluate.

In the present study, the 5E's instructional model is defined as an instructional model based on five stages, which are engage, explore, explain, elaborate and evaluate, applied by prospective teachers in their teaching classes during practicum to enhance grammar learning of secondary stage students.

\section{Grammar}

Obaid (2010, p.15) defines grammar as the logical and structural rules that govern the composition of sentences, phrases, and words in any given natural language. The term refers also to the study of such rules, and this field includes 
مجلة دراسات في المناهج وطرق التتريس، الترقيم الدولي (ISSN 2535-213X)/ العدد 244 (2019م)

morphology and syntax, often complemented by phonetics, phonology, semantics, and pragmatics.

According to Swan (2009, p.19), grammar is the rules that show how words are combined, arranged or changed to show certain kinds of meaning.

The researcher adopts this definition as it suits the purpose of secondary stage students' grammar learning that is producing correct language in different contexts using the right rules and structure.

\section{Review of Literature}

\subsection{Grammar}

\section{Phases of Grammar Teaching}

According to Carless (2009) and Maftoon (2012), teaching grammatical forms involves presentation of new language item, practice of the item under controlled conditions, and a production phase in which the learners try out the form in a more communicative context. This has been referred to as the P.P.P. approach and it forms the basis of grammar teaching.

Hence, grammar lessons are usually composed of three phases: presentation, practice, and production. One of the best ways of helping students to reach the objectives of the lesson is to introduce the new language well in the first phase of the lesson: this is the presentation phase. Then, students need to have plenty of activities to help them to practice the new language: this is the practice phase. Lastly, the students need time to use the new language they have learned in order to communicate with each other: this is the production phase 
(Brown, 2000; Harmer, 2001). The phases are presented in detail with in the following lines.

For presenting grammatical structures, there are two methods: presenting structure directly or indirectly. The Indirect method is also called the inductive presentation. The direct method is known as the deductive presentation. Thornbury $(1999, \mathrm{p} .9)$ provides the following definitions of these terms: A deductive approach starts with the presentation of a rule and is followed by examples in which the rule is applied. However, an inductive approach starts with some examples from which a rule is inferred. Common techniques of the direct method are: a) Repetition, giving a clear model and asking the students to listen and repeat two or three times; b) Writing, the teacher writes the structure clearly on the board. Then presents rules and explanations by using colored chalk or underlining important parts; c) Direct explanation, the teacher explains directly how to make a particular grammatical structure; d) Story, another way of presenting the form of grammatical structures directly is by asking the students to underline particular grammatical points in the text. Students have to find a grammatical rule. Students can do this by discussion in pairs or groups; and e) Comparison, a way of presenting the grammar directly is that the teacher writes two similar grammatical structures on the board. Students must discuss the difference in form. This technique is particularly useful when comparing different tenses.

The second phase of the lesson is practice. The teacher selects an activity that encourages meaningful repetition of the pattern. The activities should be planned in such a way that begins with controlled activities and move toward 
less controlled ones. In order to give further practice of a particular structure. It will almost certainly be necessary to prepare some kind of exercise based on the structure. There are several choices for exercise type, here are some suggestions: a) Repetition, the easiest way to practice the structure would be to do a repetition drill. The teacher presents different examples and the students repeat them; b) Substitution, the students have to fit in the structure; c) Single word prompt, the teacher gives a word as a prompt and the students give examples; d) Picture prompts, the teacher shows a picture as a prompt and the students make sentence based on the picture; and e) Free substitution, students make their own sentences based on the model that is presented by the teacher.

As for production, in this communicative phase less control over grammatical structure is exercised than during the practice phase. The aim during this phase is to have students use the structures they have been practicing in as natural and fluid way as possible.

\section{Principles of Teaching Grammar}

The presentation of grammar to learners should facilitate learning in many ways: it can provide input for noticing output and accurate forms of English; it can provide information about the communicative use of language structures by contextualizing them in spoken and written forms; it can give information implicitly through exposure to examples or explicitly through instruction on the stylistic variation of language form (Hedge, 2000 as cited in Ellis, 2006, p.84).

\section{1}


As for Thornbury (2004), the rules of teaching of grammar are as follows:

a. The rule of context: teaching grammar in context.

b. The rule of use: teaching grammar in order to facilitate the learners' comprehension and production of real language.

c. The rule of economy: economizing on presentation time in order to provide maximum practice time.

d. The rule of relevance: teaching only the grammar that students have problems with.

e. The rule of nurture: teaching does not necessarily cause learning.

f. The rule of appropriateness: interpreting all the above rules according to the levels, needs, interests, expectations and learning styles of the students (p.153).

Moreover, Ellis (2006, p.102) refers to the principles of grammar teaching from a broad sense: Grammar teaching involves any instructional technique that draws learners' attention to some specific grammatical form in such a way that it helps them either to understand it meta-linguistically and/or process it in comprehension and/or production so that they can internalize it.

\section{Previous Research on Grammar Teaching and Learning}

Grammar teaching represents a virtual domain of teaching and learning English language. Accordingly, this issue was given much attention by EFL researchers who cater for improving grammar learning via different variables. Following are some of the research conducted to improve grammar teaching and learning: 
In the study of Obaid (2010), the researcher adopted three grammar teaching approaches (the inductive, the deductive and the contextualized approaches) to develop achievement in English grammar among the eleventh graders in Khan Younis Governorate. The study indicated that there were statistically significant differences in the eleventh graders' achievement in English grammar due to the method of teaching in favor of the contextualized approach. Based on the findings, the study recommended the necessity of implementing the contextualized approach in teaching English grammar in order to bring about better outcomes in students' achievement in English language.

As for El-Tanani (2011), the aim of the study was to investigate the existing grammar teaching techniques among sixth graders in the Gaza Strip in order to suggest a practical framework of effective and appropriate techniques for teaching grammar communicatively among Palestinian sixth graders. It also aimed at investigating whether the suggested framework developed sixth graders' performance to use the language in context and inspired their attitudes to be positive towards communicative grammar teaching. The results of the data analysis showed that sixth grade English language teachers used neither effective nor appropriate techniques or procedures to teach grammar communicatively, that the suggested framework of teaching grammar communicatively proved to be effective and beneficial, and that sixth graders agreed on gaining linguistic and affective benefits from the communicative grammar teaching method.

Furthermore, the study of Ishtawi (2011) investigated the effect of game 
مجلة دراسات في المناهج وطرق التتريس، الترقيم الدولي (ISSN 2535-213X)/ العدد 244 (2019م)

strategy on the learning of English grammar among twelfth grade students at Gaza governmental schools. In the light of the findings, the researcher recommended the necessity of implementing educational game strategy in teaching English grammar to achieve better outcomes in students' achievement in English language.

Moreover, Yolgaeldili and Arikan (2011) explored the effectiveness of using games in teaching grammar to young learners from the viewpoints of Turkish EFL teachers working in primary schools. To achieve this aim, this study was designed as a descriptive study with the aim of exploring the beliefs and habits of Turkish EFL teachers' towards using games in young learners' English classes. The findings of this study showed that games are an important and necessary part of English language teaching and learning in the context of primary schools English lessons simply because they provided EFL teachers with many instructional advantages.

Similarly, Abu Shagga (2014) aimed to investigate the effectiveness of using computerized educational games on developing aspects of English grammar among deaf ninth graders in Gaza Governorates. To achieve this aim, the researcher adopted a quasi-experimental approach. The study recommended the necessity of implementing computerized games in teaching English grammar to make better outcomes in deaf students' achievement in English language.

Jigsaw Strategy was used by Saker (2015) to develop Palestinian tenth graders' English grammar learning. The findings of the study revealed that there were significant differences in learning English grammar between both 
مجلة دراسات في المناهج وطرق التتريس، الترقيم الدولي (ISSN 2535-213X)/ العدد 244 (2019م)

the experimental and the control groups in favor of the experimental group. In the light of those findings, the researcher recommended the necessity of implementing jigsaw strategy in teaching and learning English grammar to bring about better outcomes in students' achievement.

The aforementioned studies are examples of recent research conducted to improve grammar learning and teaching. They confirm the importance of grammar in English teaching and stress the continuous need for adopting new treatments to enhance grammar learning. In the present study the researcher suggests the use of the 5 E's instructional model for improving grammar learning. The model is discussed in detail in the following lines.

\subsection{The 5 E's Instructional Model}

\section{Origin of the 5 E's Model}

The 5 E's model is one of the most practical recommended models in the application of constructivist learning theory (Ozmen, 2004 and Ergin, 2006). It is built around a structured sequence and designed as a tangible and practical way for teachers to implement the constructivist theory. In other words, the model is based on constructivism which confirms that learners build or construct new ideas on top of their old ones. The origin of the model refers to 1980s when Biological Science Curriculum Study (BSCS) Team, whose leader was Rodger Bybee designed a model based on constructivist thinking. They named the model the 5E's to represent all the stages and their numbers. 
مجلة دراسات في المناهج وطرق التتريس، الترقيم الدولي (ISSN 2535-213X)/ العدد 244 (2019م)

The 5E instructional model is predicated on inquiry based learning. In this model, instructors must work with their students, who will feel more motivated to learn when they feel supported by their instructors to generate

thought-provoking questions and create hypotheses. The instructional model also promotes rational discussions as well as collaborative problem solving, which ultimately lead to understanding (Gillies, Nichols, Burgh, and Haynes, 2012).

\section{Phases of the 5 E's Model}

The 5E's model is composed of five phases: Engagement, Exploration, Explanation, Elaboration, and Evaluation (Tinker, 1997; Lorsbach, 2004; Carin and Bass, 2005; Seker and Erdem, 2017). Rodger et al. (2006, p.2) describe the phases as follows: 1) Engagement, this is an introduction to let learners access prior knowledge and engage the new concept through short activities; 2) Exploration, learners will be provided with a common base of activities to seek out for which current concepts are identified and conceptual change is facilitated; 3) Explanation, learners will be provided with opportunities to demonstrate conceptual understanding or behaviors from the data collecting; 4) Elaboration, learners will challenge conceptual understanding through new experiences to develop understanding; and 5) Evaluation, the teacher evaluates student progress toward educational objectives.

In the same concern, Senturk and Camliyer (2016, p.26) conclude that the 5E Learning cycle, developed by the BSCS group as one of the constructivist 
approach models, consists of five phases; engagement, exploration, explanation, elaboration and evaluation. The following figure summarizes these phases:

Figure1. Phases of the 5 E's Model

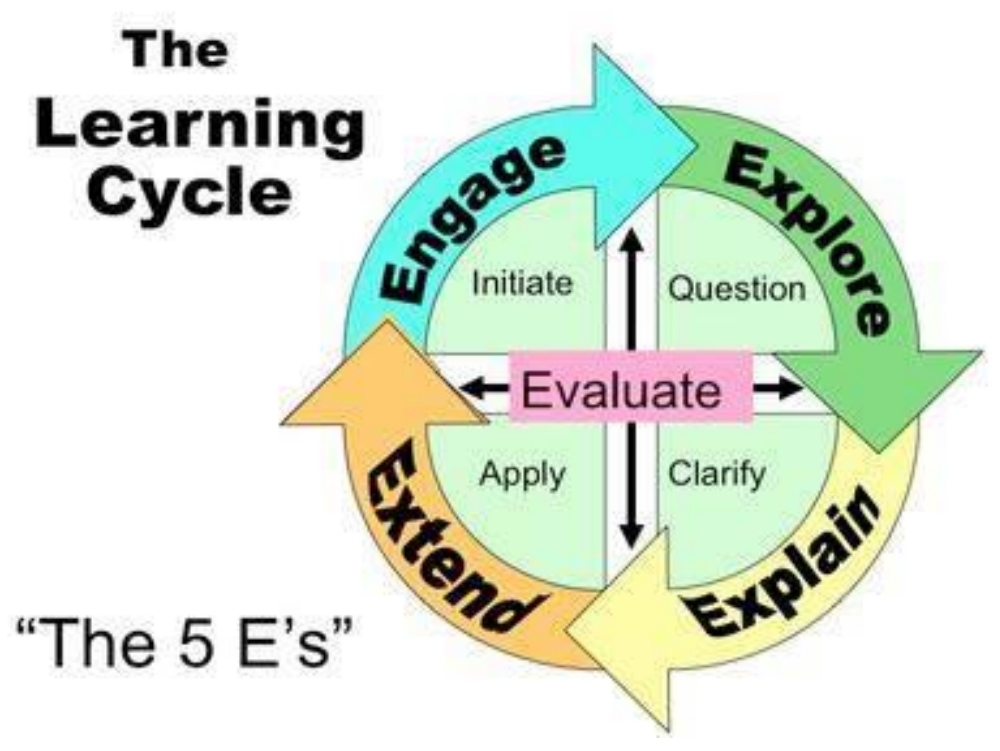

(Source: Teacher Tube, 2018)

As for the roles of both teacher and students during the learning process, the student plays an active role while the teacher is a guide as the focus is not on the product but on the process of learning. Evans (2004, p.27) confirms the role of the students during the phases. As In the instruction based on the $5 \mathrm{E}$ instructional model the students actively participate in the classes while studying, so taking on responsibilities. However, to help students achieve their role, the teacher has a responsibility. Teachers need more time for classroom preparation in order to implement the model. With 
مجلة دراسات في المناهج وطرق التتريس، الترقيم الدولي (ISSN 2535-213X)/ العدد 244 (2019م)

competent preparation, teachers achieve the benefit expected from the model. In this concern, Newby (2004) finds that the implementation of the $5 \mathrm{E}$ instructional model renders students more comfortable in the learning environment and that their achievement levels increase when experiments are included in the lessons.

\section{Previous Research on the 5 E's Model}

Some of the positive behavior and skills achieved by using the $5 \mathrm{E}$ instructional model have been expressed in terms of attaining increased success in teaching using the model, helping students to retain better concepts in their minds, achieving the development of improved attitudes and behaviour toward lessons, developing reasoning skills and superior processing skills (Brown, Collins and Duguid, 1989; Lawson, Abraham, and Renner, 1989; Brooks and Brooks, 1993; Boddy, Watson and Aubusson, 2003).

Some pioneering studies that used the model are as follows:

The study of Moseley and Reinke (2002) in which researchers report that with the help of activities based on the 5E model, students have been able to discover concepts of science and associate these concepts with situations in real life as they implemented them.

As for Balc1 (2005), the researcher designed an instruction based on the 5E instructional model finding, at the end of the instruction, that students registered significant learning and exhibited conceptual changes independent of content. 
Similarly, Ergin (2006) has made a comparison of students being exposed to the $5 \mathrm{E}$ model of instruction as opposed to those who have been taught by traditional methods, finding a significant positive difference in the group of students learning the material via the 5E model.

In the study of, Liu, Peng, Wu and Lin (2009), they found that a student group exposed to the $5 \mathrm{E}$ model recorded improvements in their scientific knowledge and perceptions.

Moreover, Yigit (2011) aimed to find out the effect of writing instruction based on the $5 \mathrm{E}$ Model on achievement and motivation. This study explored the probable effects of the 5E Model-based writing activities on promoting the achievement of students' writing skills in prep class students at Trakya University, School of Foreign Languages. According to the study results, the 5E Model-based Writing Instruction had a positive effect on promoting the students' writing skills and fostering motivation in writing.

As for Jendeya (2015), the researcher investigated the Impact of 5E model on developing tenth graders' English grammar learning and their attitudes towards English. The findings revealed that there were significant differences in learning English grammar in favor of the experimental group, as the students presented better outcome.

Concerning the study of $\mathrm{Hu}, \mathrm{Gao}$, and Liu (2017), the investigation target was novice teachers. This study investigated the effects of 5E instructional model on the teaching processes of novice teachers. First, researchers conducted a teaching design training project based on the $5 \mathrm{E}$ model for 40 
مجلة دراسات في المناهج وطرق التتريس، الترقيم الدولي (ISSN 2535-213X)/ العدد 244 (2019م)

novice teachers, and compared pre-texts of the teachers' teaching process from before the training with post-texts obtained immediately following the training to determine whether the model can promote the teaching design process of novice teachers. Results found that the 5E model had a significant effect on the improvement and further development of the teaching processes among the novice teachers.

In a new study applied by Siwawetkul and Koraneekij (2018), the researchers examined the effects of the use of a 5E instructional model

on mobile technology to enhance the reasoning ability of lower primary school students. The results revealed that the model had positive effects on reasoning ability, intrinsic motivation, reasoning behaviors, and achievement. This study presents a new trend in the application of the model as it combines it with modern technology.

There are various studies that used the 5E's model. These studies have been conducted for the purpose of investigating the impact of the $5 \mathrm{E}$ model on different school subjects and variables (Kanlı and Yagbasan, 2008; Ozturk, 2008; Acisli, Yalcin and Turgut, 2011; Turgut and Gurbuz, 2011; Uzunoz, 2011). According to Anil and Batdi (2015, p. 213), most of the research in international literature on the $5 \mathrm{E}$ instructional model has focused on students' academic achievement, their attitudes toward their lessons, conceptual changes and the adequacy of learning environments designed within the framework of the 5E model. Clearly, the model proved to be effective in various fields. Still, it is newly applied in English teaching 
مجلة دراسات في المناهج وطرق التتريس، الترقيم الدولي (ISSN 2535-213X)/ العدد 244 (2019م)

which motivated the researcher to examine its applicability and effectiveness in the TEFL class.

\section{Method}

\subsection{Design of the Study}

The study was mainly qualitative in design, using a qualitative assessment questionnaire to which the subjects responded. They also provided information about the overall experience which allowed the researcher to gather rich and in depth data about how students improved as a result of applying the suggested treatment.

\subsection{Subjects of the Study}

Ten prospective teachers applied the suggested treatment on 125 EFL students (Secondary stage, year 1) in five secondary stage classes in Rofaida Alansary public school for girls located in Port Said. The study took place in the second term of the academic year 2018-2019. Prospective teachers used the 5E's instructional model to teach English grammar. In the carried out study, it was available for prospective teachers to apply the model during practicum and for the researcher to supervise prospective teachers.

\subsection{Study Instrument}

A qualitative assessment questionnaire designed by the researcher was used for investigating improvement in students' learning of grammar and for evaluating the application of the model in English teaching. 


\section{The Qualitative Assessment Questionnaire}

To investigate the impact of using the 5 E's instructional model on secondary stage students' grammar learning, prospective teachers were asked to assess the experience of using the 5E's instructional model in their teaching by responding to the assessment questionnaire. The questionnaire had two sections: section one to which prospective teachers responded by selecting the rate they see appropriate and section two in which they give their objective opinion by answering the open-ended questions.

Section one was a 4-point scale in which (4) means fully agree, (3) means partially agree, (2) means neither agree nor disagree, and (1) means partially disagree. (For more details see Appendix A). The items included in this section investigated the model applicability, usefulness, and appropriateness to period time, number of students in the class, and students' mental level. Moreover, prospective teachers had to assess students' interaction during the lesson and students' participation in the evaluative questions at the end of the lesson. These two items were based basically on whole class observation and teacher's correction of students' answers of the evaluative in-class questions. It is worth to mention that prospective teachers were trained in the administration of the assessment technique in this study. The researcher presented sufficient illustration and modeling before allowing prospective teachers to apply class assessment.

As for section two, prospective teachers were asked to answer these questions: 
مجلة دراسات في المناهج وطرق التتريس، الترقيم الدولي (ISSN 2535-213X)/ العدد 244 (2019م)

1-What were the challenges of using the 5E's instructional model in your class?

2-Would you use the model in your teaching again? Elaborate for what purposes.

Before using the questionnaire, it was presented to a panel of jury of specialists in English curriculum and instruction (N.3) and their comments were taken into consideration.

During the administration of the questionnaire, at least two prospective teachers evaluated the teaching experience in the same class for more reliability.

Moreover, two raters analyzed and evaluated prospective teachers' responses to the two sections of the questionnaire.

\subsection{Treatment of Learning Materials}

\section{General Application Steps}

There were general steps followed by prospective teachers in their teaching using the model throughout practicum. The application procedures were based on five basic stages as follows:

The engaging stage: Prospective teachers drew the students' attention through asking questions about daily life or engaging students in an activity. The aim was to direct students to the topic and encourage them to inquire. 
مجلة دراسات في المناهج وطرق التّريس، الترقيم الدولي (ISSN 2535-213X)/ العدد 244 (2019م)

The exploring stage: Prospective teachers presented activities and models in this stage. Activities allowed students to have first-hand experience in the phenomena being observed. Models helped to build relevant experiences of the subject matter. Moreover, prospective teachers were facilitators of the communication process. The explanation stage: The students here are required to explain what they have learned by using their own words and by telling the results they reached.

The elaborating stage: Prospective teachers encouraged the students to build and expand upon the knowledge learned in the previous stages. Students see new question types about the new taught knowledge and they are expected to give answers to these questions.

The evaluation stage: Prospective teachers here catered for evaluating student's performance and determining that learning objectives have been achieved. Furthermore, they made sure there was not any misconception.

Moreover, throughout their teaching, prospective teachers used further enhancements because the lessons based on the 5E's can be enhanced to be more effective. Games, computer supported applications, and audio visual aids made the lesson more interesting and more suitable for language teaching.

\section{Sample Lesson Plan}

Prospective teachers used the 5E's model for teaching grammar lessons. In unit eleven lesson two, the topic of the lesson was " The past simple and past perfect". The sample lesson plan of teaching this lesson using the model is presented in the following table: 
مجلة دراسات في المناهج وطرق التدريس، الترقيم الدولي (ISSN 2535-213X)/ العدد 244 (2019م)

Table1. Sample Lesson Plan for Teaching The Past Simple and Past Perfect Using the 5E's Instructional Model.

\begin{tabular}{|c|c|}
\hline Lesson Number & $\begin{array}{l}\text { Unit (11), lesson (2) } \\
\text { SB page (67), WB page (66) }\end{array}$ \\
\hline The lesson Topic & The Past Simple and Past Perfect \\
\hline Implementation Time & 50 Minutes \\
\hline Stage & Secondary Stage \\
\hline Learning Outcomes & $\begin{array}{l}\text { Using past simple and past perfect correctly in oral and } \\
\text { written forms. }\end{array}$ \\
\hline Methods of Teaching & $\begin{array}{l}\text { Examination, Demonstration, Exploring, and learning by } \\
\text { doing (Included in the 5E's instructional model. }\end{array}$ \\
\hline Stages & $\begin{array}{l}\text { Engaging, Exploring, Explaining, Elaborating, and } \\
\text { Evaluating }\end{array}$ \\
\hline Engaging & $\begin{array}{l}\text {-Teacher writes the following sentence on the board: } \\
\text { I had worked at Port Said preparatory school before I } \\
\text { worked at Rofaida Alansary secondary school. } \\
\text {-Teacher asks the student the following question:" Which } \\
\text { school did I work at first?" } \\
\text {-Teacher tells the students to write the answer, or the name } \\
\text { of the school, in a sheet of paper. }\end{array}$ \\
\hline Exploring & $\begin{array}{l}\text {-Teacher asks students to raise the paper sheet to check their } \\
\text { answers. } \\
\text {-Teacher announces that the correct answer is " Port Said } \\
\text { preparatory school" } \\
\text {-Teacher asks students to write one sentence about their } \\
\text { life. The sentence should contain two actions that happened } \\
\text { in the past. } \\
\text { - In pairs, students exchange information about past actions } \\
\text { in their lives and answer the question:" Which is the earlier } \\
\text { action?" } \\
\text {-Teacher monitors students' discussion. }\end{array}$ \\
\hline Explaining & $\begin{array}{l}\text {-Teacher asks the students about the formation and usage of } \\
\text { the two tenses. } \\
\text { - After students' thinking, teacher provides them with a } \\
\text { clear explanation (structure and usage) of past simple and } \\
\text { past perfect. }\end{array}$ \\
\hline
\end{tabular}


مجلة دراسات في المناهج وطرق التدريس، الترقيم الدولي (ISSN 2535-213X)/ العدد 244 (2019م)

\begin{tabular}{|c|c|}
\hline Lesson Number & $\begin{array}{l}\text { Unit }(11), \text { lesson }(2) \\
\text { SB page }(67), \text { WB page }(66)\end{array}$ \\
\hline & $\begin{array}{l}\text { - Teacher explains that When two actions happen one after } \\
\text { the other, they can use the past perfect for the action that } \\
\text { happened first. }\end{array}$ \\
\hline Elaborating & $\begin{array}{l}\text {-Teacher writes the following sentences on the board, noting } \\
\text { that there is an earlier action (action1)and a later } \\
\text { action(action 2): } \\
\text { - They said that I was not as good as them because I } \\
\text { had come from a poorer family. } \\
\text { - It was winter and I had read in that room every day } \\
\text { for weeks. } \\
\text { - My cousin John had not known I was there so when } \\
\text { he saw me, he started to shout at me. } \\
\text { - What a kind man he had been when I first moved } \\
\text { there! } \\
\text { She had disliked me from the day that I arrived at } \\
\text {-Teacher gives the students chance to use their knowledge } \\
\text { and number the actions. } \\
\text { - Teacher discusses students' answers and presents further } \\
\text { elaboration. }\end{array}$ \\
\hline Evaluating & $\begin{array}{l}\text {-Teacher evaluates students' understanding of the topic of } \\
\text { the lesson and their ability to use past simple and past } \\
\text { perfect correctly. } \\
\text {-Teacher assesses students' discussion with concluding } \\
\text { comments. }\end{array}$ \\
\hline
\end{tabular}

Other lesson plans applied by prospective teachers in teaching grammar are available with the researcher upon request.

\section{Results and Discussion}


مجلة دراسات في المناهج وطرق التّريس، الترقيم الدولي (ISSN 2535-213X)/ العدد 244 (2019م)

Results of the study revealed the significance of the model application in the TEFL class for teaching grammar. The average of agreement percentage for each of the questionnaire items was as follows:

Table2. Section One Results of the Qualitative Assessment Questionnaire

\begin{tabular}{|l|l|c|}
\hline $\mathbf{N}$ & Item & Agreement Percentage \\
\hline 1 & Model applicability in TEFL class. & $100 \%$ \\
\hline 2 & Model usefulness for grammar teaching. & $87,5 \%$ \\
\hline 3 & $\begin{array}{l}\text { Model application appropriateness to the period } \\
\text { time. }\end{array}$ & $83 \%$ \\
\hline 4 & $\begin{array}{l}\text { Model application appropriateness to the number } \\
\text { of the students in the class. }\end{array}$ & $79 \%$ \\
\hline 5 & $\begin{array}{l}\text { Model application appropriateness to the student's } \\
\text { mental level }\end{array}$ & $66 \%$ \\
\hline 6 & Model achievement of the lesson objectives. \\
\hline 7 & $\begin{array}{l}\text { Positive interaction of the students during the } \\
\text { lesson.( Accurate recording of participants and } \\
\text { responses was required) }\end{array}$ & $83 \%$ \\
\hline 8 & $\begin{array}{l}\text { Correctness of students' answers to evaluative } \\
\text { questions. ( collection, correction, and evaluation } \\
\text { of students' written answers were required) }\end{array}$ & $87.5 \%$ \\
\hline
\end{tabular}

As shown in the previous table, calculating the average score given by prospective teachers for each item supports the positive impact of the model for teaching grammar. In other words, prospective teachers gave significant score of the qualitative assessment questionnaire items proving that the model application is significance.

Moreover, recording prospective teachers' responses to the open ended questions revealed the following results:

The challenges of using the 5E's instructional model were: 
مجلة دراسات في المناهج وطرق التتريس، الترقيم الدولي (ISSN 2535-213X)/ العدد 244 (2019م)

- Individual differences affected the smooth application of the model. For example, some students had difficulty creating their own sentences which required repetition and further elaboration.

- Time limit presented a challenge for prospective teachers who were responsible to go through five phases and achieve lesson objectives.

- Passivity of some students, although they understood the rules, created a challenge in smooth application and class evaluation.

The repetition of model application and purposes were:

- All prospective teachers agreed to use the model in their teaching again. Furthermore, they reported that they will use it definitely in grammar lessons and in other lessons rather than grammar. Some of the purposes, as they mentioned, were: practicing conversation, running up discussion in the target language, and illustrating the meaning of difficult vocabulary.

The researcher actually recommended similar educational applications for the model such as using the model to improve communication in the TEFL classroom and applying the model to teach new concepts or make a conceptual change. The researcher presented the rational and the sample lesson plan for these applications. (For more details about additional educational applications, see Appendix B).

The result of the study coincides with the findings of Obaid (2010), El-Tanani (2011), Ishtawi (2011), Yolgaeldili and Arikan (2011), Abu Shagga (2014), and Saker (2015).The present study and the aforementioned proved to be 
مجلة دراسات في المناهج وطرق التّريس، الترقيم الدولي (ISSN 2535-213X)/ العدد 244 (2019م)

effective in improving grammar of English language learners. The difference was that the present study sought the improvement of grammar learning as well as grammar teaching. The study aimed at improving grammar learning of secondary stage students and developing prospective teacher's administration of grammar lessons through a new suggested treatment. Moreover, the result of the study coincides with the findings of Reinke (2002), Balc1 (2005), Ergin (2006), Yigit (2011), Jendeya (2015), and Siwawetkul and Koraneekij (2018). These studies, as well as the present one, achieved various educational purposes by applying the 5E's instructional model.

Apparently, in the light of the study results, a different view of the model in the field of teaching English can be formed. It was rarely used in the TEFL class although well used purposefully in scientific subjects. Although as any new treatment, teachers needed proper time to fully understand the model stages and form the teaching sequence of how to apply the model in their classes, they recorded a positive assessment on model application.

\section{Conclusion and Implications}

While there are many studies on the 5E's instructional model, the majority of these studies are on science education. The primary purpose of this study was to evaluate the use of the 5 E's model as a new teaching model in TEFL classes. For teaching grammar to secondary stage students, the model proved useful and applicable as revealed in the results of the qualitative assessment questionnaire applied in the present study. However, it is important to mention that the results of the study are limited by the sample size and the instrument used. 
مجلة دراسات في المناهج وطرق التتريس، الترقيم الدولي (ISSN 2535-213X)/ العدد 244 (2019م)

Researchers and English teachers, who want to study the model and examine its effectiveness in the field of teaching English, can benefit from the theoretical background, the rationale, and the suggested sample teaching plan in this study that recommended the application of a new constructivist approach-based model in the field of teaching English for different educational purposes.

\section{Bibliography}

Abu Shagga, D. (2014). The Effectiveness of Using Computerized Educational Games on Developing Aspects of English Grammar for Deaf Ninth Graders in Gaza Governorates. Al-Azhar University, Gaza Strip, Palestine.

Acisli, S., Yalcin, S., \& Turgut, U. (2011). Effects of the 5E Learning Model on Students' Academic Achievements in Movement and Force Issues. Procedia Social and Behavioral Sciences, 15, 2459-2462.

AggulYalcın, F., \& AvincAkpınar, I. (2010). The Effect of the 5E Learning Model on Students With Different Learning Styles in Teaching the Subject of Acids and Bases. EÜFBED - Fen Bilimleri Enstitüsü Dergisi, $3(1), 1-17$.

Anil, O., \& Batdi, V. (2015). A Comparative Meta-Analysis of 5E and Traditional Approaches in Turkey. Journal of Education and Training Studies, 3(6), 212-219.

Balc1, S. (2005). Enriching the Learning of Photosynthesis and Plant Respiration Concepts in 8th Grade through the Use of the 5E Learning Model and 
مجلة دراسات في المناهج وطرق التُريس، الترقيم الدولي (ISSN 2535-213X)/ العد 244 (2019م)

Conceptual Change Texts, Unpublished Master's Thesis, ODTÜ, Educational Sciences Institute, Ankara.

Boddy, N., Watson, K., \& Aubusson, P. (2003). A Trial of the Five Es: a Referent Model for Constructivist Teaching and Learning. Research in Science Education, Netherlands: Kluwer Academic Publishers, 27-42.

Boudreault, C. (2010). The Benefits of Using drama in the ESL/EFL Classroom. The Internet TESL Journal, 16(1), 1-5.

Cakir, A. (1999). Musical Activities for Young Learners of EFL. The Internet TESL Journal, 6, 11.

Brooks, J., \& Brooks, M. (1993). In Search of Understanding: the Case for Constructivist Classrooms. Alexandria, VA: Association for Supervision and Curriculum Development.

Brown, H. (2000). Principles of Language Learning and Teaching, N.Y.: Longman.

Brown, H. (2007). Teaching by Principles: An Interactive Approach to language Pedagogy (3rd ed.) New York: Pearson Education, Inc. Longman.

Brown, J. (2006). Rhymes, Stories and Songs in the ESL Classroom. The internet TESL Journal, 12, 4.

Brown, J., Collins, A., \& Duguid, P. (1989). Situated Cognition and the Culture of Learning. Educational Researcher, 18, 32-42.

Bybee, R. (1997). Achieving scientific literacy: From purposes to practices. Portsmouth, NH: Heinemann Publications.

Bybee, R., Taylor, J., Gardner, A., Van Scotter, P., Carlson Powell, J., Westbrook, A., \& Landes, N. (2006). The BSCS 5E Instructional Model: 
مجلة دراسات في المناهج وطرق التُريس، الترقيم الدولي (ISSN 2535-213X)/ العد 244 (2019م)

Origins, Effectiveness and Applications. Retrieved March 18, 2019 from:www.bscs.org/bscs-5Einstructional-model

Carin, A. \& Bass, J. (2005). Teaching Science as Inquiry. Upper Saddle River, New Jersey. Pearson Prentice Hall.

Carless, D. (2009). Revisiting the TBLT versus PPP Debate: Voices from Hong Kong. Asian Journal of English Language Teaching, 19, 49-66.

Dang, T. \& Nguyen, H. (2012). Direct Versus Indirect Explicit Methods of Enhancing EFL Students' English Grammatical Competence: A concept Checking Based Consciousness-Raising Tasks Model. English Language Teaching, 6(1), 112- 121.

Dikici, A., Turker, H., \& Ozdemir, G. (2010). Examining the Effect of the 5E Learning Cycle on Meaningful Learning. Çukurova Üniversitesi Egitim Fakültesi Dergisi, 3(39), 100-128.

Ellis, R. (2006). Current Issues in the Teaching of Grammar: An SLA Perspective. TESOL Quarterly, 40(1), 83-107.

El-Tanani, A. (2011). Teaching Grammar Communicatively for Sixth Graders in Gaza Strip: A suggested Framework. The Islamic University, Gaza Strip, Palestine.

Ergin, I. (2006). An Example for the Effect of 5E Model on the Academic Success, Attitude, and Recognition Level of Students I Physics Education. "Projectile Motion in Two Dimensions", Ankara: Gazi University Institute of Education Sciences (Doctoral Thesis).

Evans, C. (2004). Learning with Inquiring Minds, Students are Introduced to the Unit on Gas Laws and Properties of Gases Using the 5E model. The Science Teacher, 71(1), 27-30. 
مجلة دراسات في المناهج وطرق التُريس، الترقيم الدولي (ISSN 2535-213X)/ العد 244 (2019م)

Gillies, R., Nichols, K., Burgh, G., \& Haynes, M. (2012). The Effects of Two Strategic and Meta-cognitive Questioning Approaches on Children's Explanatory Behaviour, Problem-solving, and Learning During Cooperative,

Inquiry-based Science. International Journal of Educational Research, 53, 93106.

Harmer, J. (2001). The Practice of English Language Teaching. Harlow, Essex, U. K.: Pearson Education.

Hedge, T. (2000). Teaching and Learning in the Language Classroom. Oxford: Oxford University Press.

Hu, J., Gao, C., Liu, Y. (2017). Study of the 5E Instructional Model to Improve the Instructional Design Process of Novice Teachers. Universal Journal of Educational Research 5(7), 1257-1267.

Ishtawi, H. (2011).The Effect of Game Strategy on the Learning of English Grammar for the Twelfth Grade Students . Unpublished Dissertation, The Islamic University, Gaza Strip, Palestine.

Jendeya, M. (2015). The Impact of 5E Model on Developing Tenth Graders' English Grammar Learning and their Attitudes towards English. Master Thesis, Faculty of Education, Islamic University, Gaza.

Kanli, U., \& Yagbasan, R. (2008). The Adequacy of the 7E Model-based Laboratory Approach on Students' Developing Scientific Process Skills. Gü, Gazi Eğitim Fakültesi Dergisi, 28 (1), 91-125.

Lawson, A., Abraham, M., \& Renner, J. (1989). A Theory of Instruction: Using the Learning Cycle to Teach Science Concepts and Thinking Skill. National Association of Research in Science Teaching, 1. 
مجلة دراسات في المناهج وطرق التُريس، الترقيم الدولي (ISSN 2535-213X)/ العد 244 (2019م)

Lederman, J. (2009). Levels of Inquiry and the 5 E's Learning Cycle Model. Monterey, CA: National Geographic School . Retrieved June 8, 2019 from http://www.ngspscience.com.

Liu, T., Peng, H., Wu, W., \& Lin, M. (2009). The Effects of Mobile Naturalscience Learning Based on the 5E Learning Cycle: A Case Study. Educational Technology \& Society, 12(4), 344-358.

Lorsbach, A. (2004). The Learning Cycle as a Tool for Planning Science Instruction. Illinois State University.

Maftoon, P. (2012). A Critical Look at the Presentation, Practice, Production (PPP) Approach: Challenges and Promises for ELT. Retrieved July 10, 2019 from https://www.researchgate.net

Martin, D. (2000). Elementary science methods: a constructivist approach. Belmont, CA: Wadsworth/ThomasonLearning.

Mohammed, A. \& Jaber, H. (2008). The Effects of Deductive and Inductive Approaches of Teaching on Jordanian University Students' Use of the Active and Passive Voice in English. College Student Journal, 42(2), 545553.

Moseley, C., \& Reinke, K. (2002). Cartoon and Bumber Sticker Science. Science Scope, 25(6), 32-34.

Negahdaripour, S., \& Amirghassemi, A. (2016). The Effect of Deductive vs. Inductive Grammar Instruction on Iranian EFL Learners' Spoken Accuracy and Fluency. International Journal of Applied Linguistics and English Literature, 5(1), 8-17. 
مجلة دراسات في المناهج وطرق التّريس، الترقيم الدولي (ISSN 2535-213X)/ العد 244 (2019م)

Newby, D. (2004). Using Inquiry to Connect Young Learners to Science, National Charter Schools Institute. Retrieved January 4, 2018 from http://www.nationalcharterschools. org

Obaid, O. (2010). The Effectiveness of Three Grammar Teaching Approaches on the Achievement of Secondary School Students. Unpublished Dissertation, The Islamic University, Gaza Strip, Palestine.

Orlova, N. (2003). Helping Prospective EFL Teachers Learn How to Use Songs in Teaching Conversation. Internet TESL Journal, 1(3), 187-200.

Ozmen, H. (2004). Teaching of Science and Technology Assisted Constructivist Learning Theory (Constructivist) Learning. The Turkish online J.Educ. Technol.-TOJET, 3(1).

Ozturk, C. (2008). Effect of the 5E Model on Scientific Process Skills, Academic Achievement and Attitudes in Learning Geography. Unpublished $\mathrm{PhD}$ thesis, Gazi University, Educational Sciences Institute, Ankara.

Rodger, W., Joseph, A., April, G., Pamela, V., Janet, C., Anne, W., et al.(2006). The BSCS 5E Instructional Model: Origins, Effectiveness, and Applications. Retrieved March 20, 2018 from https://tinyurl.com/y72hqy51.

Saker, S. (2015). The effectiveness of Using Jigsaw Strategy on Palestinian Tenth Graders' English Grammar Learning. Unpublished Dissertation, The Islamic University, Gaza Strip, Palestine.

Saricoban, A. \& Metin, E. (2000). Songs, Verse, and Games for Teaching Grammar. The internet TESL Journal, 6(10).

Seker, B., \& Erdem, A. (2017). Development of a Template Lesson Plan Based on 5e Model Enhanced with Computer Supported Applications and 
مجلة دراسات في المناهج وطرق التّريس، الترقيم الدولي (ISSN 2535-213X)/ العدد 244 (2019م)

Conceptual Change Texts. Journal of Education and Training Studies, $5(10), 86-94$.

Senan, D. (2013). Infusing BSCS 5E Instructional Model with Multimedia: A Promising Approach to Develop $21^{\text {st }}$ Century Skills. Manager's Journal on School Educational Technology, 9(2),1-7.

Senturk, H.,\& Camliyer, H. (2016). A New Learning Model on Physical Education: 5E Learning Cycle. Universal Journal of Educational Research 4(1), 26-29

Siwawetkul, W., Koraneekij, P. (2018). Effect of 5E Instructional Model on Mobile Technology to Enhance Reasoning Ability of Lower Primary School Students. Kasetsart Journal of Social Sciences 3, 1-6

Sunal, C., \& Haas, M. (2012). Social Studies for Elementary and Middle Grades A Constructivist Approach. ( $4^{\text {th }}$ Edition). Pearson Education.

Teachertube (2018).The Five E Model of Instruction retrieved March 18, 2018 from http://www.teachertube.com

Swan, M. (2009). Correspondence. ELT Journal 63, 300-301

Tinker, I. (1997). Practitioners and Scholars. The Women,Gender, and Development Reader, 33.

Thornbury, S. (1999). Lesson Art and Design. ELT Journal, 53(1), 4-11.

Thornbury, S. (2004). How to Teach Grammar. Longman, England.

Turgut, U., \& Gurbuz, F. (2011). Effects of Teaching with 5E Model on Students' Behaviors and their Conceptual Changes about the Subject of Heat and Temperature. International Online Journal of Educational Sciences, 3(2), 679-706. 
مجلة دراسات في المناهج وطرق التّريس، الترقيم الدولي (ISSN 2535-213X)/ العدد 244 (2019م)

Uzunoz, A. (2011). The Effects of the Activities of Current Textbook and 5E Model on the Attitude of the Students: Sample of "the Global Effects of Natural Resources Unit". Educational Research and Reviews, 6 (13), 778785.

Weaver, C., Nally, C. \& Moerman, S. (2001). To Grammar or Not to Grammar: That is Not the Question. Voices from the Middle. 8(3): 17-34.

Yigit, C. (2011). The Effect of the 5E Model in Writing on Achievement and Motivation. Master Thesis, Institute of Social Sciences, Trakya University, Turkish Republic.

Yolageldili, G. \& Arıkan, A. (2011). Effectiveness of Using Games in Teaching

Grammar to Young Learners, Elementary Education. Retrieved July 7, 2019, from http://ilkogretimonline. Org.

Zamani, A., \& Mohammadi, F. (2014). A Comparison between Using an Inductive Strategy and a Deductive one in Grammar Instruction for Iranian EFL Learners. Enjoy Teaching Journal, 2(1), 90- 98. 